\title{
Editorial
}

Dermatology

\section{St. Agnes of Rome: Patron Saint for Women with Hair Loss?}

\author{
Ralph M. Trüeb \\ Department of Dermatology, University Hospital of Zurich, Zurich, Switzerland
}

\begin{abstract}
O glorious St. Agnes, you served God in humility and confidence on earth and are now in the enjoyment of His beatific Vision in heaven because you persevered till death and gained the crown of eternal life. Remember now the dangers that surround me in the vale of tears, and intercede for me in my needs and troubles. Amen.
\end{abstract}

Prayer to St. Agnes of Rome

Roman Catholic tradition has made saints the patrons or protectors of various aspects of human life, and they are invoked for particular reasons [1]. Sometimes this is a result of actual facts, e.g. St. Blaise is invoked for throat ailments because he saved a child from suffocation due to a fish bone stuck in his throat; sometimes it is based on a detail of martyrdom, e.g. St. Laurence is invoked for burns because he was put to death by being roasted on a gridiron, and some instances result from the figurative tradition, e.g. St. Bartholomew is invoked for skin diseases since images of his martyrdom depict him with his skin draped over his arm.

The number of patron saints for skin diseases is large, and the dermatological conditions for which saints may be invoked include [2]: leprosy (St. Vincent de Paul), skin rash (St. Rose of Lima), pox (St. Matthew, St. Rita of Cascia, St. Saturninus of Toulouse), skin burns (St. John the Evangelist, St. Florian, St. Laurence of Rome), ergotism (St. Anthony the Abbot), sexually transmitted infections (St. Apollinaris, St. Denis), skin ulceration (St. Charles Borromeo), scab (St. Ignatius of Antioch), dog bite (St. Hubert, St. Vitus, St. Walburga), cancer (St. Agatha, St. Peregrine), plague (St. Aloysius Gonzaga, St. Anne, St. Benedict, St. Bruno the Carthusian, St. Christopher, St. Cyprian, St. Francis Xavier, St. Gregory the Great, St. Ignatius of Loyola, St. Catherine of Siena, St. Cosmas

\section{KARGER}

Fax +4161306 1234

E-Mail karger@karger.ch

www.karger.com (c) 2009 S. Karger AG, Basel

$1018-8665 / 09 / 2192-0097 \$ 26.00 / 0$

Accessible online at:

www.karger.com/drm and Damian, St. Roch of Montpellier, St. Rosalia, St. Sebastian, St. Thecla of Iconium), erysipelas (St. Martin of Tours, St. Andrew), snake bite (St. Paul the Apostle, St. Peter the Apostle, St. Patrick), skin wounds (St. Margaret of Antiochia), skin diseases in general (St. Bartholomew, St. Peregrine). Nevertheless, there is no patron saint for hair loss, though there are 4 patron saints for hairdressers and stylists (St. Cosmas and Damian, St. Louis IX, St. Martin de Porres and St. Mary Magdalen).

For 3 reasons, St. Agnes of Rome would seem appropriate as patron saint for women with hair loss and for trichologists, respectively: (1) the saint's historical passio, (2) her attributes in Christian iconography and (3) her feast day.

St. Agnes is a virgin martyr saint of the Roman Catholic Church and Eastern Catholic Churches. She is also acknowledged in the Church of England and the Anglican Communion as well as in Eastern Orthodoxy. According to the legend [3], St. Agnes was a member of the Roman nobility born in 291 and raised in a Christian family. She suffered martyrdom during the reign of the Roman emperor Diocletian (284-305), on January 21, 304. The prefect Sempronius wished Agnes to marry his son, and on Agnes' refusal he condemned her to death. As Roman law did not permit the execution of virgins, Sempronius dragged Agnes naked through the streets to 


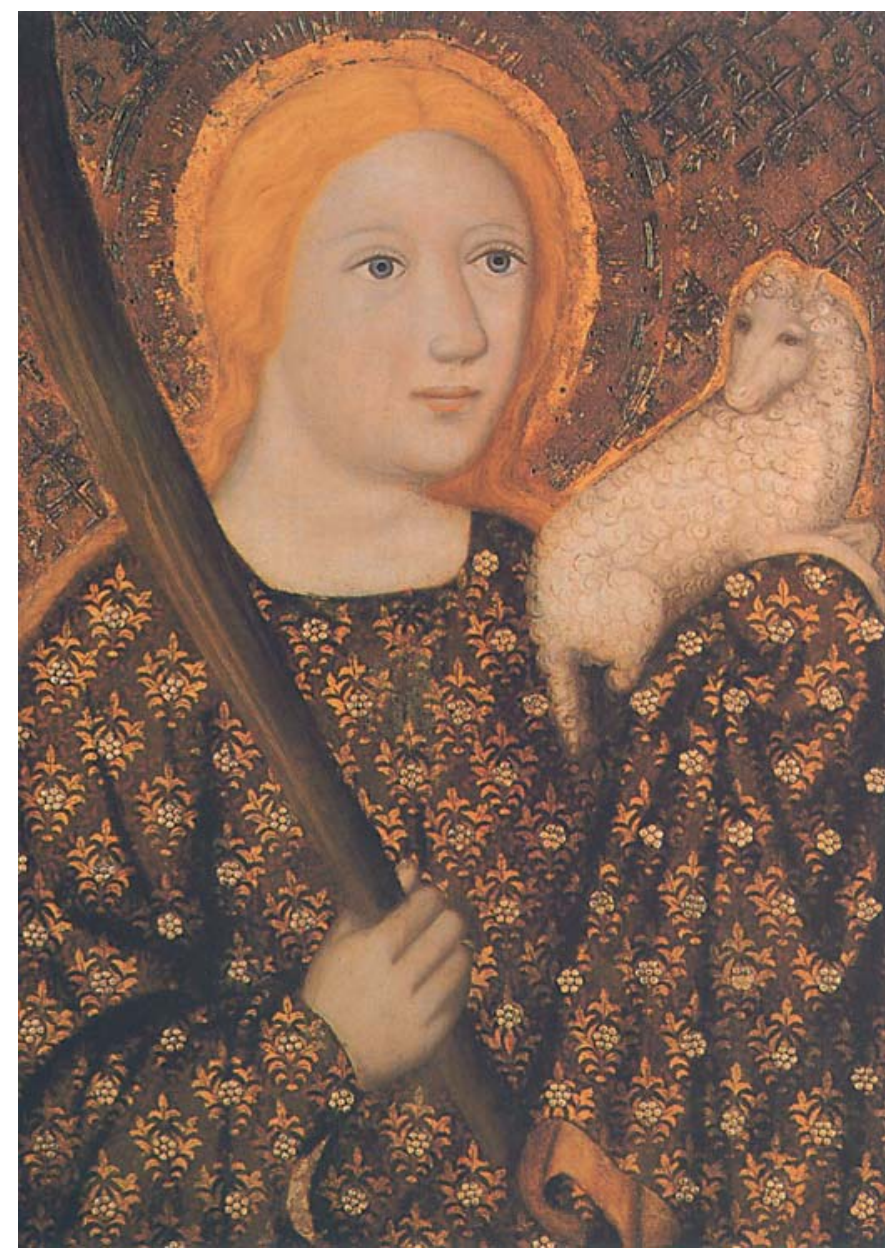

Fig. 1. St. Agnes of Rome, by Master Theodoric of Prague (14th century), panel painting in the chapel of the Holy Cross in Karlstein Castle.

a brothel. As she prayed, her hair grew and covered her body. When led out to die she was tied to a stake, but the bundle of wood would not burn, whereupon the officer in charge of the troops drew his sword and beheaded her, or, in some other texts, stabbed her in the throat. In the 4 th century, Constantia, the daughter of the Roman emperor Constantine (reign 312-337), built a basilica at the site of her tomb. Agnes' bones are conserved in the church of Sant' Agnese fuori le mura in Rome, built over the catacomb that housed Agnes' tomb. Her skull is preserved in a side chapel in the church of Sant' Agnese in Agone in Rome's Piazza Navona. St. Ambrose (338-397) wrote about Agnes in De Virginitate, Pope Damasus I (pope from 366 to 384) wrote an epitaph for her, and Prudentius (348-405) composed a hymn in her honor. Hundreds of churches are named in honor of St. Agnes, including two major well-known churches and one Anglican cathedral in Kyoto, Japan. Traditionally, St. Agnes of Rome is regarded as patron saint of chastity, girls, betrothed women (she chose Christ as her betrothed), rape victims, virgins and gardeners, since virginity is symbolized as a closed garden. There is a narrative poem by John Keats (17951821), called The Eve of Saint Agnes (1819). It is a romantic poem with a mediaeval setting, about an elopement the night before St. Agnes' Day. The tie-in with Agnes is that she is regarded as the patron of young unmarried girls, and there is a folk belief that a girl who goes to bed supperless on the eve of St. Agnes's Day will dream that night about her husband-to-be.

In art, St. Agnes is depicted with a lamb as her attribute (fig. 1), since her name resembles the Latin word 'agnus,' which means 'lamb'. The name is actually derived from the Greek word 'agnon' meaning 'chaste, pure, sacred'. In the past, her feast day was the occasion for the blessing of the lambs whose wool was used by the nuns of St. Agnes in Rome to weave the palliums of archbishops. Notably, the Australian Hair and Wool Research Society is one of the original and major international, non-profit organizations bringing together premier doctors and scientists involved in the treatment and research of hair disorders.

Finally, in this issue of Dermatology, Kunz et al. [4] demonstrate - in a study of 823 otherwise healthy women presenting with the complaint of hair loss in the Hair Consultation Clinic, Department of Dermatology, University Hospital of Zurich, for trichograms between 2001 and 2007 - periodicity in the growth and shedding of hair with a minimum of telogen percentage following the feast day of St. Agnes of Rome on January 21 (the day of her martyrdom). A second feast on January 28, which commemorated her birthday, was suppressed as one of the second feasts of a single saint by Pope John XXIII (pope from 1958 to 1963) in 1960, before the Second Vatican Council [5].

References Loyola Press, 2006.

2 Gory E: Lexikon der Heiligen, ed 6. Munich, Deutscher Taschenbuch-Verlag, 2005.

3 Die Legenda Aurea: Das Leben der Heiligen erzählt von Jacobus de Voragine, ed 14, transl from Latin by Richard Benz. Gütersloh, Gütersloher Verlagshaus, 2004, pp 103-106.

$\checkmark 4$ Kunz M, Seifert B, Trüeb RM: Seasonality of hair shedding in healthy women complaining of hair loss. Dermatology 2009; 219:105-110.

5 Attwater D, John CR: The Penguin Dictionary of Saints, ed 3. New York, Penguin Books, 1993. 